\title{
Seasonal differences in migration strategies of Red Kites (Milvus milvus) wintering in Spain
}

\author{
Jorge García-Macía ${ }^{1}$ (D ) Javier Vidal-Mateo ${ }^{1} \cdot$ Javier De La Puente ${ }^{2} \cdot$ Ana Bermejo $^{2} \cdot$ Rainer Raab $^{3} \cdot$ Vicente Urios $^{1}$
}

Received: 5 April 2021 / Revised: 12 July 2021 / Accepted: 14 July 2021 / Published online: 29 July 2021

(c) The Author(s) 2021

\begin{abstract}
Red Kite shows a great variability in its migration strategies: most individuals in north-eastern Europe are migrants, but there is also a growing number of sedentary individuals. Here, we tagged 49 Red Kites wintering in Spain with GPS/satellite transmitters between 2013 and 2020 to study the autumn and spring migration between the breeding or summering areas in Central Europe and the wintering quarters in Spain. In first place, differences between immatures and adults were found for spring migration. Adults began the spring migration towards the northeast in February-March while the immature individuals began to migrate significantly later and showing a wider date range (February-June). Adults also takes significantly less days to arrive at their destinations (12 \pm 5 days) and cover more distance per day $(134.2 \pm 37.1 \mathrm{~km} /$ day $)$ than immatures $(19 \pm 11$ days and $98.9 \pm 21.2 \mathrm{~km} /$ day). In second place, we also found differences between spring and autumn migration (excluding immatures). Spring migrations were clearly faster and with less stopovers days than autumn migrations. Autumn migration began between mid-October and late November and two different behaviours were observed: most birds made a quick migration direct to the wintering areas with only some days of stopovers, but others prolonged the migration with long stops along the route. These results highlight a great variation in the migratory movements of Red Kite, not only according to age but also between individuals and seasons.
\end{abstract}

Keywords Raptors $\cdot$ Short-distance migration $\cdot$ GPS transmitters $\cdot$ Movement ecology $\cdot$ Migration speed

\section{Zusammenfassung}

\section{Saisonale Unterschiede in den Zugstrategien von in Spanien überwinternden Rotmilanen (Milvus milvus)}

Rotmilane weisen eine große Variabilität bei den Zugstrategien auf: Die meisten Individuen in Nordosteuropa sind Zugvögel, aber es gibt auch eine wachsende Anzahl an sesshaften Individuen. Wir haben 49 Rotmilane, die zwischen 2013 und 2020 in Spanien überwinterten, mit GPS-/Satellitensendern ausgestattet, um den Herbst- und Frühlingszug zwischen den Brutoder Überwinterungsgebieten in Mitteleuropa und den Winterquartieren in Spanien zu untersuchen. Zunächst wurden beim Frühjahrszug Unterschiede zwischen Jungtieren und Erwachsenen festgestellt. Erwachsene begannen im Februar-März mit dem Frühjahrszug nach Nordosten, während die immaturen Individuen deutlich später begannen und eine größere Zeitspanne (Februar-Juni) aufwiesen. Adulte Individuen brauchten auch deutlich weniger Tage, um ihr Ziel zu erreichen (12 \pm 5 Tage) und legten mehr Strecke pro Tag zurück $(134,2 \pm 37,1 \mathrm{~km} / \mathrm{Tag})$ als Jungtiere (19 \pm 11 Tage und 98,9 $\pm 21,2 \mathrm{~km} /$ Tag). Außerdem fanden wir auch Unterschiede zwischen Frühjahrs- und Herbstzug (ohne Jungtiere). Der Frühjahrszug war

Communicated by N. Chernetsov.

Jorge García-Macía

jorgegarciamacia97@gmail.com

1 Vertebrates Zoology Research Group, University of Alicante, Apdo. 99, 03080 Alicante, Spain

2 Bird Monitoring Unit, SEO/BirdLife, C/Melquiades Biencinto, 34, 28053 Madrid, Spain

3 Technisches Büro für Biologie Mag. Dr. Rainer Raab, Quadenstrasse 13, 2232 Deutsch-Wagram, Austria 
deutlich schneller und mit weniger Zwischenstopptagen als der Herbstzug. Der Herbstzug begann zwischen Mitte Oktober und Ende November und es wurden zwei verschiedene Verhaltensweisen beobachtet: Die meisten Vögel machten einen schnellen Zug direkt in die Überwinterungsgebiete mit nur einigen Zwischenstopps, andere verlängerten den Zug mit langen Zwischenstopps entlang der Route. Diese Ergebnisse zeigen eine große Variation in den Zugbewegungen des Rotmilans, nicht nur abhängig vom Alter, sondern auch von den Individuen und den Jahreszeiten.

\section{Introduction}

The Red Kite is a species from the western Palearctic, restricted mainly to Europe, with a population of 25,200-33,400 pairs (BirdLife International 2019). It declined globally in the last decades due to persecution and poisoning, although many populations have increased the number of individuals in the recent years (Aebischer 2010; Molina 2015; BirdLife International 2019) and currently it is considered as "Near threatened" by the International Union for Conservation of Nature and Natural Resources (IUCN 2018). Spain is the third country with the most numerous breeding population, after Germany and France (Knott et al. 2009; BirdLife International 2019) and the species is listed as "In danger of extinction" according to the Spanish Catalogue of Threatened Species.

Unlike the long-distance migratory raptors, such as the Black Kite (Milvus migrans) with a well-defined long-distance migratory behaviour (Panuccio et al. 2014), the Red Kite has a great intra-specific variability in its migration ecology. Most Red Kites in north-eastern Europe are intracontinental migrants, and they spend the wintering season mainly in southern France, Spain and Portugal (Del Hoyo et al. 1994), but there is also a growing number of sedentary individuals in Central Europe (Aebischer 2010; BirdLife International 2019). In addition, there are resident populations in the wintering countries of birds coming from the northeast, as it is the case of Spain. Spain is the main winter destination for the species, with an estimated wintering population of 50,297 individuals according to the last census (Molina 2015). Birds start the autumn migration between August and November, and they return to their breeding areas between February and April (Snow and Perrins 1998; Pfeiffer and Meyburg 2009).

Knowledge of complete life cycles, and therefore of migration, is essential to understand the dynamics of populations and to develop appropriate conservation plans (Both et al. 2006; Newton 2008; Jones and Cresswell 2010). Although there are some works on the movement ecology during the breeding and wintering season of the Red Kite (e.g., Heredia et al. 1991; Nachtigall et al. 2003; Nemček 2013; Pfeiffer and Meyburg 2015), studies focused on their migration are scarce and mostly based on direct visual observations or ring recoveries (Kjellen 1992, 1994; Urcun and Bried 1998; Nachtigall 2008). Using satellite transmitters,
Pfeiffer and Meyburg (2009) described their migration between Thuringia (Germany) and Spain, but due to the accuracy of the tags available at that time, they could not examine some migratory characteristics. More recently, Litérak et al. (2019) explore the migration of four immatures from Austria to their settlement areas in the south of their range, although far from the wintering quarters of our individuals, and Maciorowski et al. (2019) described juveniles dispersal and their mortality on the breeding population in western Poland. As mentioned above, Spain has a great importance for the Red Kite, with a large breeding population and the main winter destination. Therefore, here we study the autumn and spring migration between the breeding or summering areas of Central Europe and the wintering quarters in Spain, where the individuals were captured and tagged with GPS and satellite transmitters for explain better the migratory strategies of this raptor. Our main objectives are: (1) to identify the migration routes between the wintering and breeding areas; (2) to estimate some migratory parameters (i.e., departure and arrival dates, duration of migration, migration speed and stopovers days); and (3) to evaluate the differences according to age.

\section{Methods}

\section{Tagging and data collection}

Between 2013 and 2020, 49 Red Kites were captured during their wintering season in Spain in different provinces: Álava (19), Huesca (15), Segovia (10) and Toledo (1). There were 22 adults and 27 immatures (when they were tagging); between them, 6 males, 7 females and 33 with not determined sex. We considered individuals as "immatures" when they were in their first spring migration. We consider individuals as "adults" after their second autumn migration (included). Birds were trapped using an automatic clap net on the ground triggered remotely and baited with carrion. Individuals were weighed and ringed, and a blood sample was taken in some cases according to ethical standards before birds release for DNA sexing with molecular techniques (Ellegren 1996). Birds were tagged using a GPS or satellite transmitter that was affixed to the back using a Teflon harness, a non-abrasive material, tied with a cotton thread (Garcelon 1985). Weight of tags represented between 
1.6 and $3.4 \%$ of bird's body mass (mean $=2.3, \mathrm{SD}=0.4$ ), which was below the recommended 5\% (Kenward 2001) and birds were released a maximum of 30 min after capture.

We used five transmitter models: 20-21-g SAKER GPSGSM (Ecotone Telemetry; $n=9$ ), 22-g PTT-100 solarpowered Argos/GPS (Microwave Telemetry Inc.; $n=3$ ), 18-g solar PTT 45"-bat (North Star Science and Technology; $n=2$ ), 35-g GPS-GSM transmitter (North Star Science and Technology; $n=2$ ) or 20-25-g OrniTrack-20 and OrniTrack-25 solar powered GPS-GSM tracker (Ornitela; $n=23$ ). Ecotone tags were programmed to collect locations every hour from 06:00 to 19:00 (local hour); Microwave tags 1 loc every $2 \mathrm{~h}$ from 06:00 to 18:00 h, except between 1 February -31 March and 1 October to 30 November with $1 \mathrm{loc} / \mathrm{h} ; 35$-g North Star tags recorded locations from 10:00 to $16: 00 \mathrm{~h}$ every $2 \mathrm{~h} ; 18$-g tags with a duty cycle of 12-h ON/12-h OFF and Ornitela tags recorded data every 5 min from nautical dusk in the morning to nautical dusk in the evening, when the battery level was sufficient. Birds tagged with Argos transmitters were only used for general calculation of timing, migration duration and daily distance, but not for hourly speeds, due to their lower precision. To avoid biases associated with the non-independence of locations, positions separated $<1 \mathrm{~h}$ after the previous one were excluded from the analyses (Limiñana et al. 2007).

\section{Migratory parameters and analysis}

For each spring or autumn migration, we identified the onset and the end dates, and the migration duration. In the case of immature individuals, tracked autumn migrations correspond to the second one, since they were captured at the wintering areas after the first autumn migration. The overall migration distance was calculated as the distance between the first and last migration points following a beeline. Migration tracks were divided into daily segments, using one location per night trying to choose the last of the day (Limiñana et al. 2012). With these daily segments, we calculated the average distance covered in a day for each migration (as the average of each migration day) excluding segments longer than 1 day and the stopover days (when a bird moved less than $25 \mathrm{~km} /$ day; Strandberg et al. 2009). We also calculated the flight speed (the distance covered hourly), considering only locations obtained with $<2 \mathrm{~h}$ of difference, excluding the stopover days and using only values $>5 \mathrm{~km} / \mathrm{h}$, which represent birds in active flight (Mellone et al. 2012a).

All the different migratory parameters (i.e., departure and arrival date, migration duration, distance/day, number of stopover days and flight speed) were compared between immatures and adults for the spring migrations and between autumn and spring. For this purpose, we performed Linear Mixed Models (LMM's) including as dependent variables number of days of migration, number of stopover days, daily distances (km/day) and speed $(\mathrm{km} / \mathrm{h})$. "Age" and "season" were considered as fixed factors and "individual" and "year" were considered as random factors. A model was developed for each fixed factor because we had different sample. To evaluate the flight speed according to hour of the day (considering only intervals with $<4 \mathrm{~h}$ of difference), we used the Kruskal-Wallis test (data were non-normal) and the multiple comparison Games-Howell test (Zar 1999), to check whether there was any peak of activity. All statistical analyses were performed with R. 4.0.5 and significance level was established at $P<0.05$.

\section{Results}

Of the 49 tagged Red Kites, data were recorded for 83 spring migrations (Table S1, Fig. 1) and 39 autumn migrations (partially for 5 of these by failure of the transmitter; Table S2, Figs. 2 and 3). After the spring migration towards the northeast, the countries of destination where the Red Kites had their breeding areas (or where they spent the summer in the case of immatures) were mainly Germany (36 individuals) and Switzerland (9 individuals), but also France (3, including 2 immatures that moved to Germany and Switzerland finally), Poland (2 individuals), Austria (1 individual) and Denmark (1 individual). The traveled distances between the winter quarters in Spain and breeding or summering areas ranged between $287 \mathrm{~km}$ (a bird that moved from the Spanish province of Huesca to southern France) and $1764 \mathrm{~km}$ (an individual who migrated from the Spanish province of Álava to western Poland).

\section{Spring migrations}

Adults Red Kites began to migrate on average on 26 February, ranging between the last week of January and midApril. They arrive at their destinations in Central Europe on average on 10 March, ranging between the first week of February and the last week of April (Table S1). They take $14 \pm 5$ (SD) days to complete the migration, with $2 \pm 3$ stopovers days (range $=0-11)$. Adults covered distance was $134.2 \pm 37.1 \mathrm{~km} /$ day (maximum distance of $253.4 \pm 92.1 \mathrm{~km} /$ day) and flight speed was $18.2 \pm 4.3 \mathrm{~km} / \mathrm{h}$.

Immatures Red Kites began to migrate on average on 8 April, ranging between mid-February and first week of June. They arrive at their destinations in Central Europe on average on 26 April, ranging between the first week of March and the last week of June (Table S1). They take $19 \pm 11(\mathrm{SD})$ days to complete the migration, with $5 \pm 6$ stopovers days (range $=0-20$ ). Immatures covered distance was $98.9 \pm 21.2 \mathrm{~km} /$ day (maximum distance of $217.1 .4 \pm 41.2 \mathrm{~km} /$ day) and flight speed was $16.8 \pm 3.4 \mathrm{~km} / \mathrm{h}$. 
Fig. 1 Spring migration routes of 49 Red Kites tracked by GPS and satellite telemetry between the wintering quarters in Spain and the breeding/summering areas in Central Europe
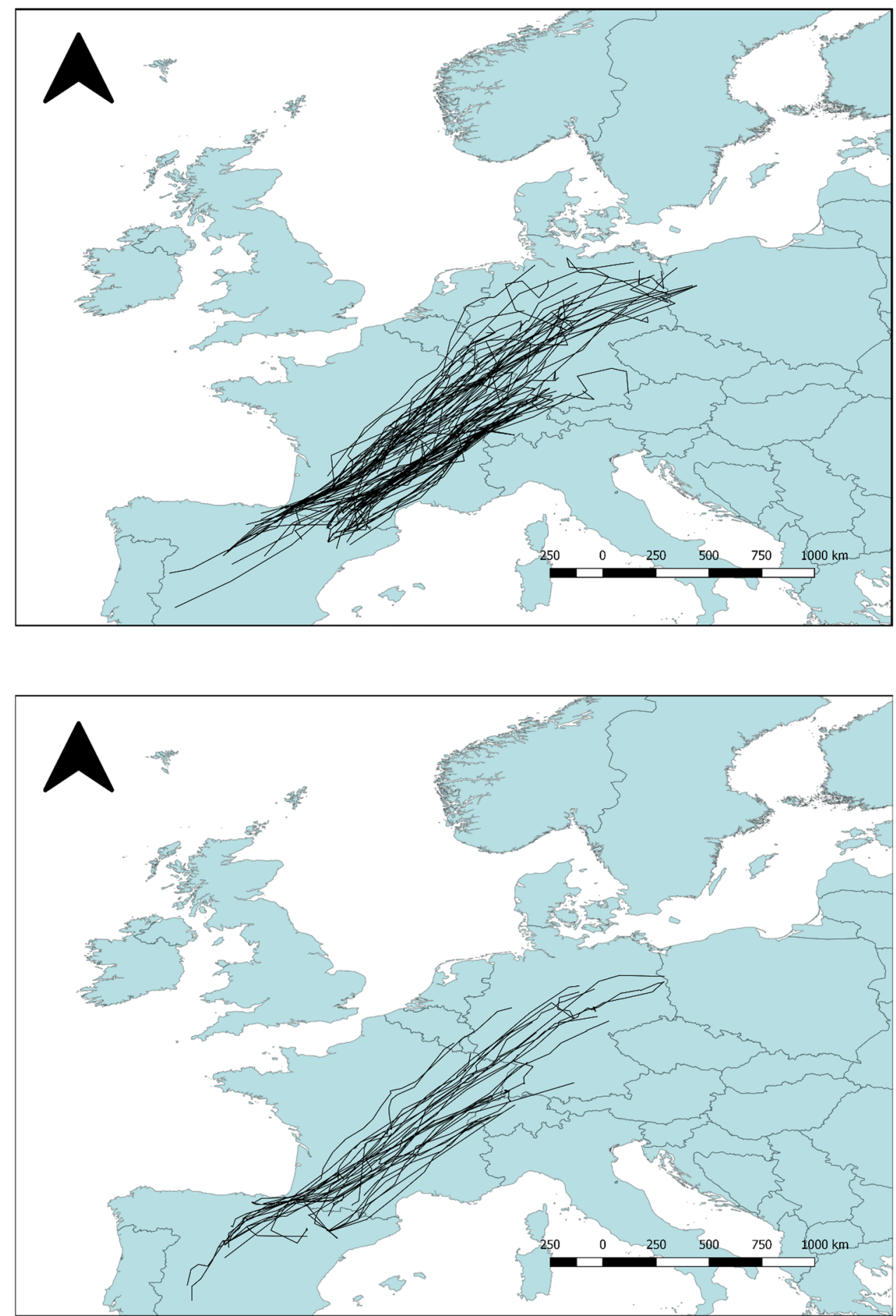

Fig. 2 Autumn migration routes of 20 Red Kites tracked by GPS and satellite telemetry between their breeding/summering areas in Central Europe and wintering quarters in Spain
There were significant differences between adults and immatures for duration of migration $(p=0.049)$ and daily distance $(p=0.007)$. There were not significant differences for the number of stopover days $(p=0.095)$ and flight speed $(p=0.11)$ (Table 1$)$.

The flight speeds ( $n=59,053$ segments) were different according to time of day $\left(\chi^{2}=22,874.5, \mathrm{~d} f=23, p<0.001\right)$; although there was not a prominent peak of activity, higher speeds occurred during the central hours of day (local time, Fig. 4).

\section{Autumn migrations}

All Red Kites were adults in the autumn migrations we tracked. They began to migrate on average on 20 October, ranging between the last week of August and 
Fig. 3 Autumn migration routes of three Red Kites tracked by GPS telemetry that performed long stops along the journey (17-45 days; white triangles) between their breeding areas in Central Europe and the wintering quarters in Spain. \#ECOTONE53: Doble line (purple circle means stopover days); \#REKI 4: cut line (white circles with black points inside); \#REKI13: solid line (white triangles)

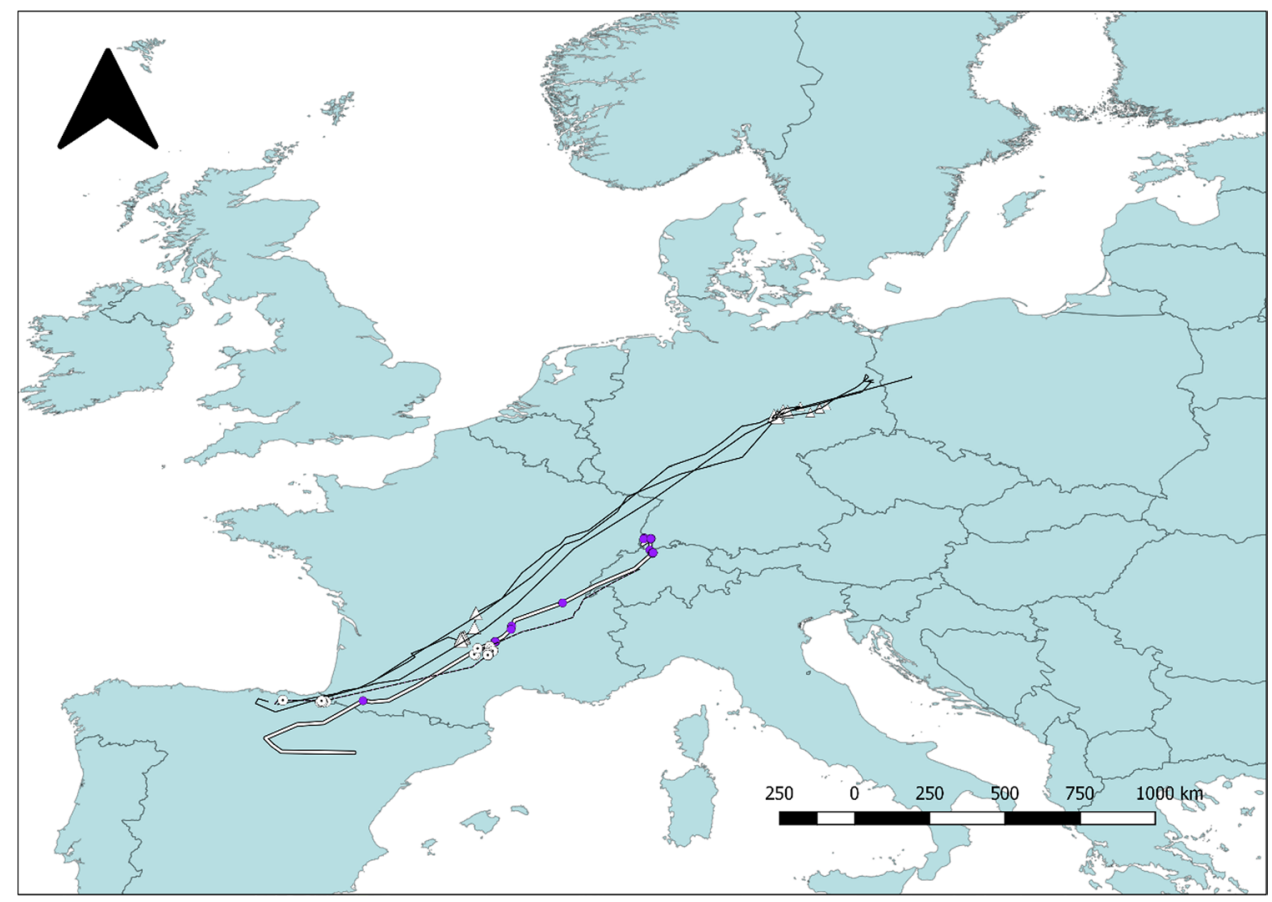

Table 1 Linear mixed models (LMM's) estimates of fixed effects

\begin{tabular}{|c|c|c|c|c|c|c|}
\hline Variable & Factor & Estimate & SE & $\mathrm{d} f$ & $F$ value & $p$ value \\
\hline \multirow[t]{2}{*}{ Days } & Intercept & 15.32 & 0.92 & 2.47 & 81.98 & 0.006 \\
\hline & Age & -3.33 & 0.85 & 6.26 & 5.89 & 0.049 \\
\hline \multirow[t]{2}{*}{ Stopover days } & Intercept & 3.22 & 0.46 & 1.64 & 6.78 & 0.147 \\
\hline & Age & -1.44 & 0.46 & 6.15 & 3.89 & 0.095 \\
\hline \multirow[t]{2}{*}{ Daily distance (km/day) } & Intercept & 119.88 & 6.42 & 3.45 & 295.93 & $<0.001$ \\
\hline & Age & 13.86 & 4.12 & 45.96 & 7.89 & 0.007 \\
\hline \multirow[t]{2}{*}{ Hourly distance $(\mathrm{km} / \mathrm{h})$} & Intercept & 14.38 & 2.62 & 5.83 & 33.16 & 0.001 \\
\hline & Age & 0.85 & 0.51 & 61.98 & 2.62 & 0.11 \\
\hline \multicolumn{7}{|c|}{$\begin{array}{l}\text { b. Comparison between spring and autumn migrations (excluding immatures and the three individuals with long stopovers during autumn } \\
\text { migration) }(n=79)\end{array}$} \\
\hline \multirow[t]{2}{*}{ Days } & Intercept & 17.01 & 1.28 & 2.805 & 111.23 & 0.002 \\
\hline & Season & 4.85 & 0.88 & 58.99 & 24.87 & $<0.001$ \\
\hline \multirow[t]{2}{*}{ Stopover days } & Intercept & 2.57 & 0.67 & 4.21 & 10.79 & 0.029 \\
\hline & Season & 1.21 & 0.40 & 69.041 & 8.27 & 0.005 \\
\hline \multirow[t]{2}{*}{ Daily distance (km/day) } & Intercept & 110.95 & 5.64 & 2.55 & 233.04 & 0.001 \\
\hline & Season & -21.22 & 3.881 & 46.85 & 21.76 & $<0.001$ \\
\hline \multirow[t]{2}{*}{ Hourly distance $(\mathrm{km} / \mathrm{h})$} & Intercept & 12.20 & 2.37 & 5.97 & 25.42 & 0.002 \\
\hline & Season & -2.53 & 0.52 & 46.22 & 22.71 & $<0.001$ \\
\hline
\end{tabular}

Bold values indicate that $p$ values $<\alpha(=0.05)$

A and B includes Age and Season as fixed factors, respectively. Year and Individual were considered as random effects. Standard error (SE), degrees of freedom $(\mathrm{d} f), F$ value and $p$ value are shown for each LMM

mid-December. They arrive at their destinations in Spain on average on 21 November, ranging between the first week of December and the last week of January
(Table S1). They take $32 \pm 25$ (SD) days to complete the migration, with $14 \pm 23$ stopovers days (range $=0-82$ ). 


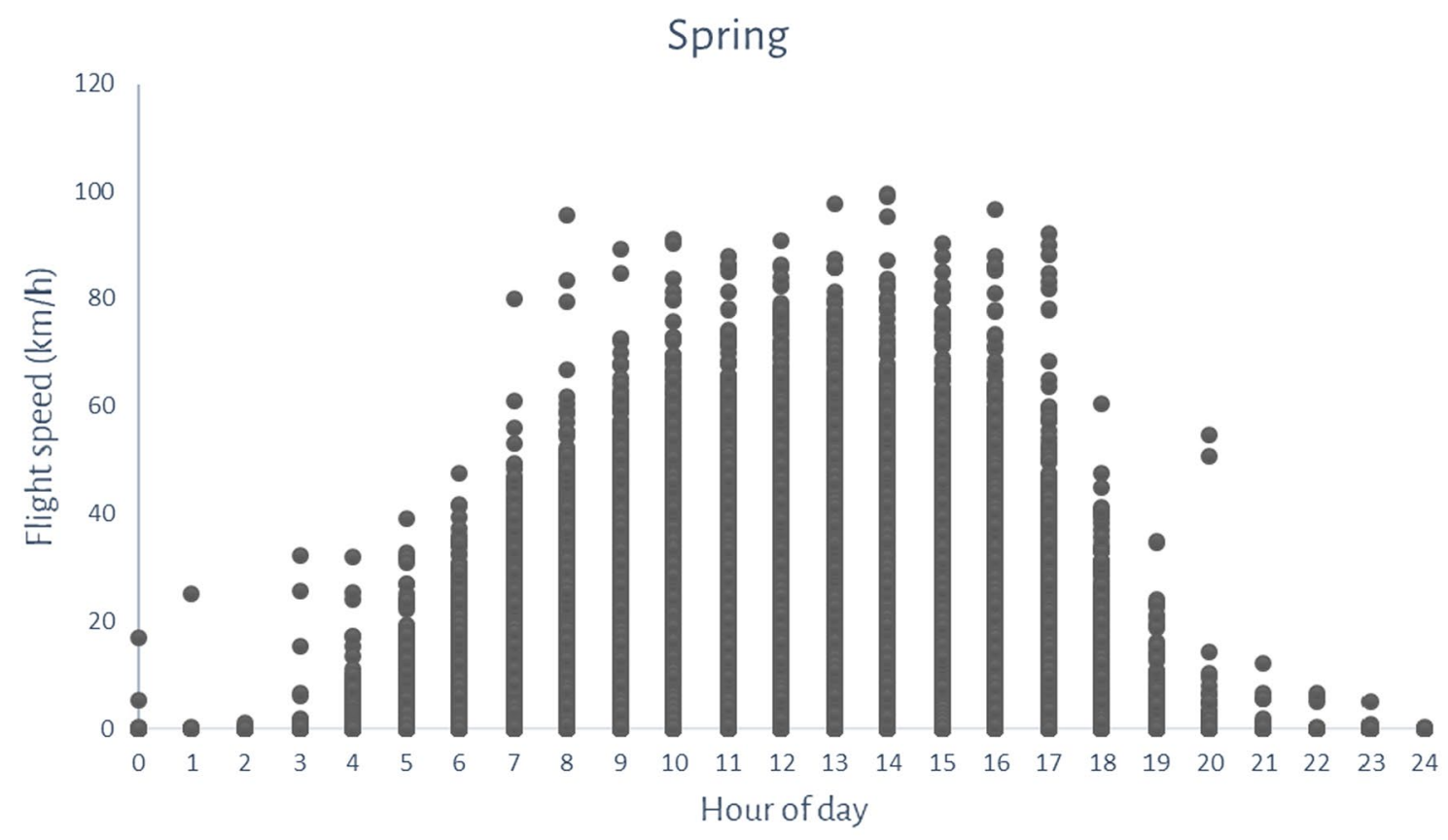

Autumn

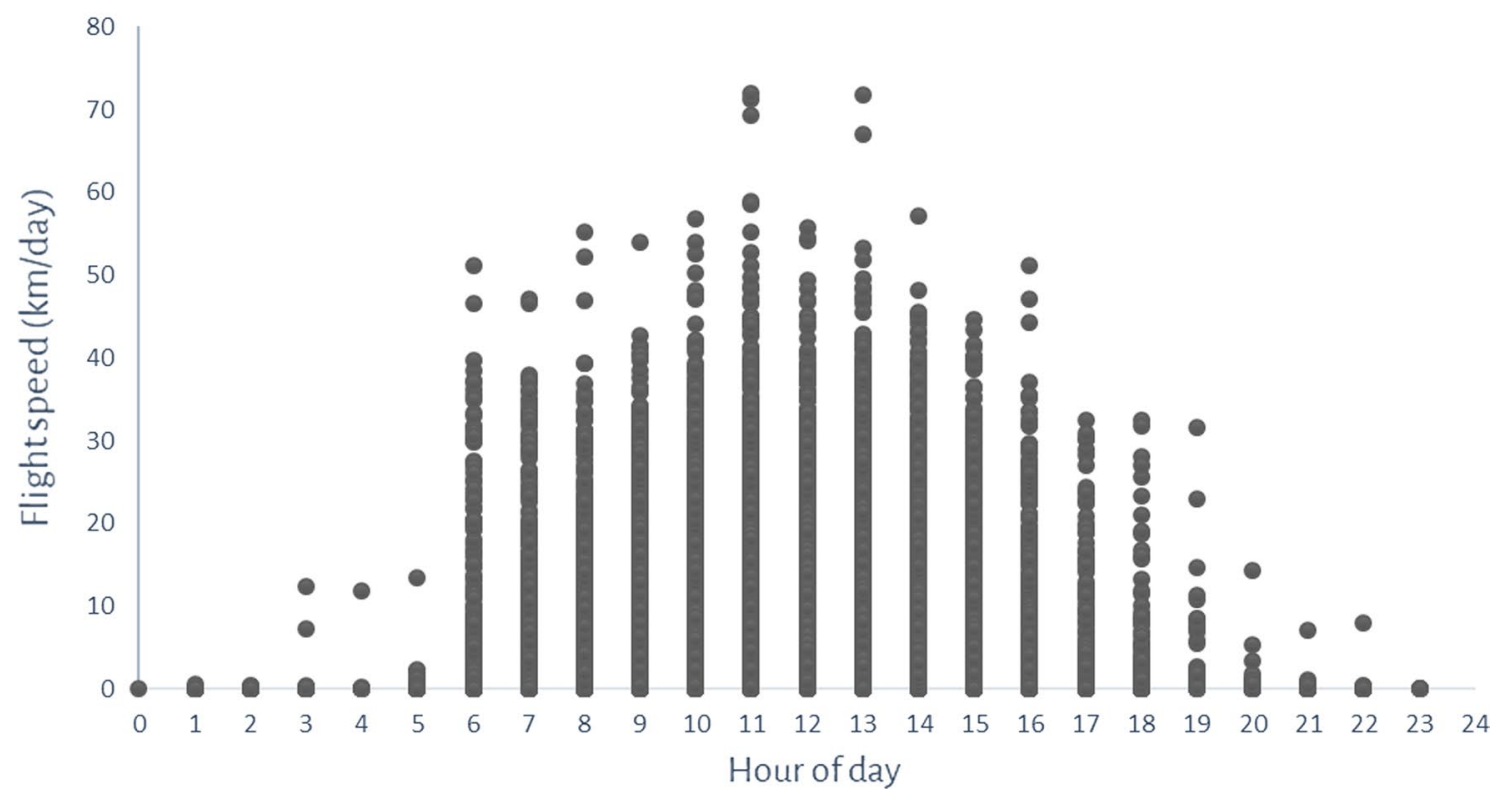

Fig. 4 Flight speed $(\mathrm{km} / \mathrm{h})$ during the spring and autumn migrations between Spain and Central Europe according to hour of day of 49 Red Kites

They covered $86.2 \pm 17.7 \mathrm{~km} /$ day (maximum distance of $187.7 \pm 44.3 \mathrm{~km} /$ day) and flight speed was $13.5 \pm 3.5 \mathrm{~km} / \mathrm{h}$.

As during spring migrations, flight speeds $(n=12,375$ segments) were different according to time of day $\left(\chi^{2}=4886.60, \mathrm{~d} f=23, p<0.001\right)$ and although there was no a prominent peak of activity, higher speeds occurred during the central hours of day (Fig. 4).

Three individuals, \#REKI04, \#REKI13 and \#ECOTONE53 (with 1, 3 and 1 registered autumn migrations, respectively), did not make direct migration journeys to their wintering areas in Spain with only a few days of stopover, but they stopped for longer periods (between 45 and 17 days) in one or several zones where they made short displacements until they resumed the travel (Fig. 3). Therefore, their migrations lasted longer, delaying the arrival date to Spain. \#REKI04 after starting the migration from Switzerland on 30 October, stopped in an area in the south of France from 11 November until 26 December, when it 
resumed the journey to the south; it stopped again on 6 January in the northern Spain until 23 January, when it finally returned to the wintering area where it had been captured the previous season. \#REKI13 in the migration of autumn 2015, coming from western Poland, from 11 September it moved slowly through the east of Germany, until 10 October when it resumed the return to its wintering area in Spain. In 2016, he also stopped in an area of eastern Germany from 6 October to 2 November, then it traveled southward and it remained in an area of the center of France for 42 days; on 4 January it moved further south, where it stayed until the migration of spring, in this case without returning to the area of Spain where it was captured. In 2017 this behaviour was repeated: from 17 to 27 September it moved slowly to the eastern Germany, where it remained until 29 October when it traveled this time to its wintering area in northern Spain arriving on 13 November. \#ECOTONE53 moved initially from its breeding area in Germany at the start of the 2019 autumn migration, but it stopped for about 28 days (until 20 September). After that, it continued to the south $40 \mathrm{~km}$ just for a day and stopped again 19 days (until 11 October), when it continued to its wintering area in Spain.

Red Kites showed a high fidelity towards their wintering quarters in Spain: 16 of 21 individuals tracked for various season $(76.10 \%)$ returned during the autumn migration to the area they had occupied during the previous season at least once, some of them after several consecutive seasons.

\section{Differences between spring and autumn migrations}

Comparing the spring and autumn migrations (excluding immatures for spring migrations and the three individuals that made long stops during the autumn migration), there were significant differences between them for all parameters (Table 1): the duration of migration $(p<0.001)$, the number of stopover days $(p=0.005)$, the daily distances $(p<0.001)$ and the flight speed $(p<0.001)$.

\section{Discussion}

Germany was the main destination where tagged Red Kites wintering in Spain moved during the spring migration (70\% of individuals). This country has the largest breeding populations of the species, with 12,000-18,000 pairs (BirdLife International 2019). The second main destination was Switzerland, with 1200-1500 pairs and where the breeding population has increased in the last decades (Aebischer 2009; Knott et al. 2009).

Adult Red Kites began the spring migration towards Central Europe in February and March, while the immatures had a wider date range (with the onset of migration between February and June) and they began to migrate significantly later than the adults, arriving to the summer areas also later. According to migration theory, this difference in timing of migration between adults and immatures (Mueller et al. 2003) could be due to the competition for breeding resources to which adults are subjected: Red Kites usually start to breed at 2-4 years of age (Newton et al. 1989; Evans et al. 1999; Carter 2001) and they have to ensure a good breeding site (Kokko 1999). This competition also explains why spring migration is faster than autumn migration (Alerstam 2006; Nilsson et al. 2013). However, this last behaviour has not been observed in some species, being also influenced by landscape characteristics, environmental factors and food availability (Mellone et al. 2015; Kölzsch et al. 2016; Schmaljohann 2018).

We have no information about the first autumn migration from immature Red Kites due they were tagged in their first winter after this first migration, but previous studies tagged a few individuals at nest and tracked them during their first autumn migration (Literak et al. 2019; Maciorowski et al. 2019). During the autumn migration we have found dual strategy: three individuals interrupted their migratory journey to the South making long stops along the route (Fig. 3), although most of the birds flew straight to their winter quarters with only some few days of stopover (Fig. 2). Comparing the autumn migration of these last Red Kites with the spring migration in the adult birds, the Red Kites complete the spring migration in less days and with higher covered distances per day, as have been reported for other species of raptors (Schmaljohann 2018). More variability was found in the duration of autumn migration than in spring, maybe due to the absence of the pressure of having a good breeding site (Kokko 1999). Urcun and Bried (1998) reported that immature Red Kites tend to migrate later than older individuals in autumn. However, Kjellen (1992, 1994) observed an earlier mean departure of immatures. Our results showed an overlap in the departure dates of adults and immatures, so probably migration is spread over the same period.

The three individuals that made long stops during migration (\#REKI4, \#REKI13 and \#ECOTONE53) delayed the arrival date to their final wintering destinations in some of the autumn migrations. Along migration they stopped in different areas where remained doing short displacements, until they restarted the journey towards the South (this behaviour was observed in \#REKI13 in 3 consecutive years). Pfeiffer and Meyburg (2009) observed stopovers of several days, as we did in some of the birds, but the stops observed in these three individuals reached up to month and a half. Some species have a similar strategy, like Red-backed Shrike (Lanius collurio), which stops for several weeks in the Sahel before reaching the final winter destination in Southern Africa (Tøttrup et al. 2012). In this way, Red Kites prolonged the autumn migration within the winter season. This strategy possibly allows the Red Kites to exploit different food 
resources in suitable areas without the need to continue migrating. Red Kites have a generalist diet, with a marked scavenging tendency visiting vulture restaurants or dumps, but also feeds on small mammals, birds, reptiles or amphibians (Cramp and Simmons 1980), so they can vary their diet according to food availability (Blanco et al. 1990; García et al. 1998).

We have observed that in general, Red Kites returned to the same wintering area that they had occupied the previous year (e.g., \#123,735, a bird that spend the winter during 6 consecutive years in the same area), although with some exceptions. Nachtigall (2008) observed this site fidelity, but also individuals that changed their wintering areas the following year. The wintering site fidelity is a common feature among migrating raptors (Alerstam et al. 2006; Chevalier et al. 2010; García-Ripollés et al. 2010; López-López et al. 2014; Mellone et al 2012b; Strandberg et al. 2008; Trierweiler et al. 2013; Vidal-Mateo and Urios 2017) and it could be due to a better knowledge of the territory and the availability of resources, although more studies are necessary to understand the causes of the possible variations.

The daily distances recorded for the Red Kites were lower than those of other soaring migratory raptors, such as Black Kite (Meyburg and Meyburg 2009; Panuccio et al. 2014; Sergio et al. 2014), Marsh Harrier Circus aeruginosus (Strandberg et al. 2008), Egyptian Vulture (López-López et al. 2014) or Booted Eagle (Mellone et al. 2015), with distances around $200-250 \mathrm{~km} /$ day. These last are transSaharan migrants that have to face different ecological barriers (Strandberg et al. 2010). Comparing with a European short-distance migrant, the Common Buzzard Buteo Buteo (on average $84 \mathrm{~km} /$ day; Strandberg et al. 2009), the daily distance during autumn migration were higher for the Red Kite, although with a similar range. These differences could be very influenced by the overall migration distance (Alerstam et al. 2003).

Knowledge of migration routes is essential for raptors conservation. Klaassen et al. (2014) highlighted that mortality rate is about six times higher during migration seasons than during stationary periods (breeding or wintering). Furthermore, mortality of Red Kites (and many other raptors) mainly occurs during their juvenile dispersal (Katzenberger et al. 2019; Maciorowski et al. 2019), when they do not know the territory, which also suggests that rambling movements and long stopovers in random areas, like we found in some individuals during autumn migrations, may increase mortality. For those reasons, despite Red Kites have high plasticity due to their high individual variability in their spatial and migration strategies, this could be negative for their survival. On the other hand, it is necessary to protect not only the breeding areas, but also the shared migration routes and their stopover areas, specially avoiding wind turbines concentration (Schaub 2012).
In summary, this study provides new information on the intra-continental migration routes of the Red Kite between Spain and Central Europe, the migratory strategies and some parameters. According to our data, immature birds started the spring migration from Spain later than the adults and with a wider date range, arriving to the summer areas in Central Europe also later. There were significant differences the autumn and the spring migrations: Red Kites migrated in spring in less days and with higher daily distances. In addition, the autumn migration evidenced a great variation in the movements of Red Kites, with different migration strategies: birds that perform a short-term migration and others that prolong the migration with long stops, combining migration and wintering.

Supplementary Information The online version contains supplementary material available at https://doi.org/10.1007/s10336-021-01918-5.

Acknowledgements Information about tagged Red Kites has been obtained within the 'Migra' project (http://www.migraciondeaves.org/ en) developed by SEO/BirdLife, with the collaboration of Fundación Iberdrola España. We are grateful to all volunteers that helped during all the fieldwork. We are thankful to Gobierno de Aragón, Diputación de Araba, Junta de Castilla y León and Junta de Castilla-La Mancha for giving all the necessary permissions. Funding for the tagging was provided by Fundación Iberdrola España, Gobierno del País Vasco, Fundación Biodiversidad, Grupo Ornitológico SEO-Monticola, FAB and Binaced townhall. NorthStar donated two GPS-GSM prototype units to deploy on Kites. J. Vidal-Mateo is supported by a FPU grant of Spanish Ministry of Education (reference FPU014/04671). This paper is part of Jorge García-Macía's PhD.

Funding Open Access funding provided thanks to the CRUE-CSIC agreement with Springer Nature.

Open Access This article is licensed under a Creative Commons Attribution 4.0 International License, which permits use, sharing, adaptation, distribution and reproduction in any medium or format, as long as you give appropriate credit to the original author(s) and the source, provide a link to the Creative Commons licence, and indicate if changes were made. The images or other third party material in this article are included in the article's Creative Commons licence, unless indicated otherwise in a credit line to the material. If material is not included in the article's Creative Commons licence and your intended use is not permitted by statutory regulation or exceeds the permitted use, you will need to obtain permission directly from the copyright holder. To view a copy of this licence, visit http://creativecommons.org/licenses/by/4.0/.

\section{References}

Aebischer A (2009) Der Rotmilan: ein faszinierender Greifvogel. Haupt Verlag, Bern

Aebischer A (2010) Distribution and recent population changes of the Red Kite in the Western Palaearctic-results of a recent comprehensive inquiry. Proc Int Red Kite Symp 209:12-14

Alerstam T (2003) Bird migration speed. In: Berthold P, Gwinner E, Sonnenschein E (eds) Avian migration. Springer-Verlag, Berlin, pp 253-267 
Alerstam T (2006) Strategies for the transition to breeding in timeselected bird migration. Ardea 94:347-357

Alerstam T, Hake M, Kjellen N (2006) Temporal and spatial patterns of repeated migratory journeys by ospreys. Anim Behav 71:555-566

BirdLife International (2019) Milvus milvus (amended version of 2016 assessment). IUCN Red List Threat Spec. https://doi.org/10.2305/ IUCN.UK.2017-1.RLTS.T22695072A110921280.en

Blanco JC, Hiraldo F, Heredia B (1990) Variations in the diet and foraging behaviour of a wintering red kite (Milvus milvus) population in response to changes in food availability. Ardeola 37:267-278

Both C, Bouwhuis S, Lessells CM, Visser ME (2006) Climate change and population declines in a long distance migratory bird. Nature 441:81-83

Carter I (2001) The red kite. Arlequin Press, Chelmsford, UK

Chevallier D, Jiguet F, Nore T, Baillon F, Cavallin P (2010) Satellite tracking of a booted eagle Aquila pennata during migration. Ring Migr 25:62-64

Cramp S, Simmons KEL (1980) Handbook of the birds of Europe, the Middle East and north Africa. The birds of the western palaearctic, vol 2. Oxford University Press, Oxford

Del Hoyo J, Elliott A, Sargatal J (1994) Handbook of the birds of the world new world vultures to guineafowl, vol 2. Lynx Editions, Barcelona

Ellegren H (1996) First gene on the avian W chromosome (CHD) provides a tag for universal sexing of non-ratite birds. Proc R Soc B 263:1635-1641

Evans IM, Summers RW, O’Toole L, Orr-Ewing DC, Evans RD, Snell N, Smith J (1999) Evaluating the success of translocating Red Kites Milvus milvus to the UK. Bird Study 46:129-144

Garcelon DK (1985) Mounting backpack telemetry packages on bald eagles. Institute for Wildlife Studies, Arcata, California

García JT, Viñuela J, Sunyer C (1998) Geographic variation of the winter diet of the Red Kite Milvus milvus in the Iberian Peninsula. Ibis 140:302-309

García-Ripollés C, López-López P, Urios V (2010) First description of migration and wintering of adult Egyptian vultures Neophron percnopterus tracked by GPS satellite telemetry. Bird Study 57:261-265

Heredia B, Alonso JC, Hiraldo F (1991) Space and habitat use by red kites Milvus milvus during winter in the Guadalquivir marshesa comparison between resident and wintering populations. Ibis 33:374-381

IUCN (2018) The IUCN red list of threatened species. Version 2018-1. www.iucnredlist.org. Accessed 22 Aug 2018.

Jones T, Cresswell W (2010) The phenology mismatch hypothesis: are declines of migrant birds linked to uneven global climate change? J Anim Ecol 79:98-108

Katzenberger J, Gottschalk E, Balkenhol N, Waltert M (2019) Longterm decline of juvenile survival in German Red Kites. J Ornithol 160:337-349

Kenward RE (2001) A manual for wildlife radio tagging. Academic Press, London

Kjellen N (1992) Differential timing of autumn migration between sex and age groups in raptors at Falsterbo. Sweden Ornis Scand 23(4):20-434

Kjellen N (1994) Differences in age and sex-ratio among migrating and wintering raptors in southern Sweden. Auk 111:274-284

Klaassen RHG, Hake M, Strandberg R, Koks BJ, Trierweiler C, Exo K-M, Bairlein F, Alerstam T (2014) When and where does mortality occur in migratory birds? Direct evidence from long-term satellite tracking of raptors. J Anim Ecol 83:176-184. https://doi. org/10.1111/1365-2656.12135

Knott J, Newbery P, Barov B (2009) Action plan for the red kite Milvus milvus in the European Union. BirdLife International for the European Union, Europe
Kokko H (1999) Competition for early arrival in migratory birds. J Anim Ecol 68:940-950

Kölzsch A, Müskens GJDM, Kruckenberg H, Glazov P, Weinzierl R, Nolet BA, Wikelski M (2016) Towards a new understanding of migration timing: slower spring than autumn migration in geese reflects different decision rules for stopover use and departure. Oikos 125:1496-1507

Limiñana R, Soutullo A, Urios V (2007) Autumn migration of Montagu's Harriers Circus pygargus tracked by satellite telemetry. J Ornithol 148:517-523

Limiñana R, Romero M, Mellone U, Urios V (2012) Mapping the migratory routes and wintering areas of Lesser Kestrels Falco naumanni: new insights from satellite telemetry. Ibis 154:389-399

Literák I, Raab R, Petretto M, Škrábal J, Spakovszky P, Steindl J (2019) Diverse natal dispersal in four sibling red kites originating from Austria, including wintering in Tunisia. Biologia 75:1399-1407

López-López P, García-Ripollés C, Urios V (2014) Individual repeatability in timing and spatial flexibility of migration routes of transSaharan migratory raptors. Curr Zool 60:642-652

Maciorowski G, Kosicki J, Polakowski M, Urbanska M, Zduniak P, Tryjanowski P (2019) Autumn migration of immature Red Kites Milvus milvus from a central European population. Acta Ornithol 54:45-50

Mellone U, Klaassen RHG, Garcia-Ripolles C, Limiñana R, LopezLopez P, Pavon D, Strandberg R, Urios V, Vardakis M, Alerstam T (2012a) Interspecific comparison of the performance of soaring migrants in relation to morphology, meteorological conditions and migration strategies. PLoS ONE 7(7):e39833

Mellone U, López-López P, Limiñana R, Urios V (2012b) Wintering habitats of Eleonora's Falcons Falco eleonorae in Madagascar. Bird Study 59:29-36

Mellone U, De la Puente J, López-López P, Limiñana R, Bermejo A, Urios V (2015) Seasonal differences in migration patterns of a soaring bird in relation to environmental conditions: a multiscale approach. Behav Ecol Sociobiol 69:75-82. https://doi.org/ 10.1007/s00265-014-1818-4

Meyburg BU, Meyburg C (2009) GPS-Satelliten-Telemetrie bei einem adulten Schwarzmilan (Milvus migrans): Aufenthaltsraum während der Brutzeit, Zug und Überwinterung. Populationsökologie Greifvogel Und Eulenarten 6:243-284

Molina B (2015) El milano real en España. III Censo Nacional. Población invernante y reproductora en 2014 y método de censo. SEO/BirdLife, Madrid

Mueller HC, Berger DD, Mueller NS (2003) Age and sex differences in the timing of spring migration of hawks and falcons. Wilson Bull 115:321-324

Nachtigall W, Stubbe M, Herrmann S (2003) Aktionsraum und Habitatnutzung des Rotmilans (Milvus milvus) im Winter-eine telemetrische Studie im Nordharzvorland. J Ornithol 144:284-294. https://doi.org/10.1046/j.1439-0361,2003.03005.x

Nachtigall W (2008) Der Rotmilan (Milvus milvus L. 1758) in Sachsen und Sudbrandenburg-Untersuchungen zu Verbreitung und Ökologie. PhD thesis, University of Halle-Wittenberg, Germany

Nemček V (2013) Movements of a juvenile red kite Milvus milvus in the border zone of Austria, Slovakia and the Czech Republic. Slovak Raptor J 7:43-48. https://doi.org/10.2478/srj-2013-0005

Newton I (2008) The migration ecology of birds. Academic Press, London

Newton I, Davis PE, Davis JE (1989) Age of first breeding, dispersal and survival of Red Kites Milvus milvus in Wales. Ibis 131:16-21

Nilsson C, Klaassen RH, Alerstam T (2013) Differences in speed and duration of bird migration between spring and autumn. Am Nat 181:837-845 
Panuccio M, Agostini N, Mellone U, Bogliani G (2014) Circannual variation in movement patterns of the Black Kite (Milvus migrans migrans): a review. Ethol Ecol Evol 26:1-18

Pfeiffer T, Meyburg BU (2009) Migratory and wintering behaviour of the Red Kite Milvus milvus in Thuringia (Germany) as revealed by satellite telemetry. Vogelwarte 47:171-187

Pfeiffer T, Meyburg BU (2015) GPS tracking of Red Kites (Milvus milvus) reveals fledgling number is negatively correlated with home range size. J Ornithol 156:963-975

Schaub M (2012) Spatial distribution of wind turbines is crucial for the survival of red kite populations. Biol Conserv 155:111-118

Schmaljohann H (2018) Proximate mechanisms affecting seasonal differences in migration speed of avian species. Sci Rep 8:4106. https://doi.org/10.1038/s41598-018-22421-7

Sergio F, Tanferna A, De Stephanis R, López Jiménez L, Tavecchia G, Preatoni D, Hiraldo F (2014) Individual improvements and selective mortality shape lifelong migratory performance. Nature 515:410-413

Snow DW, Perrins CM (1998) The birds of the western palearctic, non-passerines, vol 1. Oxford University Press, Oxford

Strandberg R, Klaassen RHG, Hake M, Olofsson P, Thorup K, Alerstam T (2008) Complex timing of Marsh Harrier Circus aeruginosus migration due to pre- and postmigratory movements. Ardea 96:159-171

Strandberg R, Alerstam T, Hake M, Kjellen N (2009) Short-distance migration of the common buzzard Buteo buteo recorded by satellite tracking. Ibis 151:200-206

Strandberg R, Klaassen RHG, Hake M, Alerstam T (2010) How hazardous is the Sahara Desert crossing for migratory birds? Indications from satellite tracking of raptors. Biol Lett 6:297-300
Tøttrup AP, Klaassen RHG, Strandberg R, Thorup K, Kristensen MW, Jorgensen PS et al (2012) The annual cycle of a trans-equatorial Eurasian-African passerine migrant: different spatio-temporal strategies for autumn and spring migration. Proc R Soc B Biol Sci 279:1008-1016

Trierweiler C, Mullie WC, Drent RH, Exo K, Komdeur J, Bairlein F, Harouna A, Bakker M, Koks BJ (2013) A palaearctic migratory raptor species tracks shifting prey availability within its wintering range in the Sahel. J Anim Ecol 82:107-120

Urcun JP, Bried J (1998) The autumn migration of red kite Milvus milvus through the pyrenees. In: Chancellor RD, Meyburg BU, Ferrero JJ (eds) Holarctic birds of prey. ADENEX \& WWGBP, Berlin, pp 641-654

Vidal-Mateo J, Urios V (2017) Ecología durante el periodo invernal. In: Urios V, Bermejo A, Vidal-Mateo J, De la Puente J (eds) Migración y ecología espacial de la población española de águila calzada, Monografía n. 2 del programa Migra. SEO/BirdLife, Madrid, pp 63-71

Zar JH (1999) Biostatistical analysis, 4th edn. Prentice Hall, Upper Saddle River, USA

Publisher's Note Springer Nature remains neutral with regard to jurisdictional claims in published maps and institutional affiliations. 